\title{
The Mute Zone of Social Representations and the Effects of (Un)Masking: Review and Prospects
}

\author{
Patrick Rateau ${ }^{1} \mathbb{D}^{\otimes}$, Grégory Lo Monaco ${ }^{2} \mathbb{D}$ \\ ${ }^{1}$ Paul Valéry University Montpellier 3, \\ 1 Rue du Professeur Henri Serres, Montpellier, 34080, French Republic \\ ${ }^{2}$ Aix-Marseille University, \\ 52 Avenue Escadrille Normandie-Niemen, Marseille, 13013, French Republic \\ $\checkmark$ patrick.rateau@univ-montp3.fr
}

\begin{abstract}
Twenty years ago, Guimelli and Deschamps (2000) hypothesised the existence of the mute zone of social representations. According to the authors, certain parts of the social representations of objects, described as "sensitive", were not expressed under normal survey conditions. This fundamental question was curiously addressed very late in literature on social representations, but has been having significant success within the community of researchers working in this field since then. This seminal work, which offered a methodological perspective capable of highlighting such unspoken facts, paved the way for studies that proposed several theoretical interpretations and new techniques for exploring this 'mute zone'. The challenge was twofold: to identify the processes involved and to invent the appropriate tools to express the counter-normative contents potentially attached to certain objects of representation. This article proposes to take stock of these 20 years of research and to anticipate new avenues oriented on the one hand on the study of the socio-cognitive processes involved in the mute zone phenomenon, and on the other hand on the proposal of new theoretical and methodological articulations with other concepts dealing with similar issues.
\end{abstract}

Key words: mute zone, social representations, (un)masking, social comparison, behaviour, power, methodology

\section{Introduction}

Would you always tell anyone what you really think about anything? Of course not - that is why this question has been widely debated in the Humanities and Social Sciences, as it questions the validity of the answers collected when human individuals are asked about their opinions on certain objects. It mainly covers three facets: the first relates to the 'always' and refers to the effects of the context in which the answers are obtained (for example, the differences between a situation of anonymity and a situation of visibility). The second (the 'anyone') concerns the interviewer's influence on the person they are interviewing,

(C) Rateau P., Lo Monaco G., 2021

(c) () This work is licensed under a Creative Commons Attribution 4.0 International License https://creativecommons.org/licenses/by/4.0/ 
such as status, gender or ethnicity. The third (the 'anything') refers to the effect of the object about which opinions are sought, with some objects being more 'sensitive' than others regarding the norms and values that are attached to those. In addition to the theoretical issues involved, they also question researchers regarding the need to develop collection techniques that can best approximate the 'true' opinions of the respondents.

In social psychology, these questions have been at the heart of the study of stereotypes and prejudices. Several methodological options have been considered in this context in order to get individuals to express attitudes that cannot be expressed in usual conditions of collection: indirect measures (Fazio et al., 1986), the bogus pipeline technique (Jones, Sigall, 1971), the randomised response technique (Warner, 1965; Himmelfarb, Lickteig, 1982), the experimenter effect technique (Anderson, Silver, Abramson, 1988; Campbell, 1981; Davis, 1997; Fazio et al., 1995); Finkel, Guterbock, Borg, 1991; Gilbert, Hixon, 1991; Schuman, Converse, 1971; Stangor et al., 2002; Sudman, Bradburn, 1974) or implicit measures (Fazio, Olson, 2003), the most famous of which is the Implicit Association Test (IAT; Greenwald, Banaji, 1995). A synthesis about these aspects has been proposed by Albarracin, Johnson and Zanna (2005). It is only recently that research dealing specifically with social representations has found interest in this question through the study of what Guimelli and Deschamps (Deschamps, Guimelli, 2002, 2004) referred to as the 'mute zone' of social representations. This term refers to the idea that several elements of the representational field could be 'masked' by individuals with regards to certain objects, and thus made mute as they are not expressed in a usual context of collection of opinions. This phenomenon had already been observed by Moscovici (1961) in his seminal research on the representation of psychoanalysis: some of the elements of psychoanalytic theory were not mentioned by individuals. This was notably the case for the notion of 'libido'. According to the author, this absence was explained by the action of an ambient value system marked by prohibitions concerning sexuality. In the same sense, Jodelet (1989) had noticed that certain dimensions of the representation of mental illness, related to the belief in its contagiousness, were not always verbalised by individuals. According to the author, this was due to their archaic and anxietyprovoking character. These examples suggest that if social representations are globally constructed in conformity with the norms and values of social groups, they can also sometimes integrate beliefs contrary to these norms and values, which then become verbally hidden by individuals.

Therefore, with Guimelli and Deschamps, we can hypothesise that by reducing the normative pressure to which the subjects questioned about psychoanalysis or mental illness were subjected, they could have expressed this type of belief. Several methods were imagined to lift this normative pressure.

\section{Methodological approaches}

Three types of procedures have been considered in order to lead individuals to 'unmask' some of their opinions regarding 'sensitive' objects: manipulation of the public vs. private context of responses, normative decontextualization and substitution technique. 


\section{Private and public context}

The manipulation of a context of expression that is anonymous and private or, on the contrary, visible and public, has been used for a long time outside the research on social representations (e.g., Klein et al., 2003; Klein, Livingston, Snyder, 2005), but it has also been applied to objects that are closely related to the questions addressed by the work on the mute zone. The aim of manipulating the private versus public context is indeed to cause inhibition or, on the contrary, to facilitate the expression of socially undesirable content (Piermattéo et al., 2014). In this regard, one can highlight the work done on the expression of prejudice against African-Americans (Stangor et al., 2002), or the work done on whether or not to report driving behaviour under the influence of alcohol (Lajunen, Summala, 2003). From this perspective, the differences highlighted between the private and public contexts of expression reveal a strategy for managing self-impression (e.g., Goffman, 1959; Kuran, 1995; Lajunen, Summala, 2003). Thus, following the example of research conducted by Hidalgo (2012), Lajunen and Summala (2003) and Stangor et al. (2002), the work conducted by Piermattéo et al. (2014) confirms the relevance of manipulating such a context in order to reveal counter-normative aspects associated with the objects studied. These aspects are always expressed more in a public context of expression than in a private context. Moreover, the results observed by Piermattéo et al. (2014) prove to be quite consistent with those observed by Guimelli and Deschamps (2000) concerning gypsies using another methodological option: the substitution technique.

\section{The substitution technique}

This method of exploration of the mute zone is inspired by the identification paradigm initiated by Jellison and Green (1981). It consists of not soliciting the expression of participants by their own name, but on behalf of someone else to whom the participants are asked to substitute themselves in order to respond. Thus, Guimelli and Deschamps (2000) show that individuals more frequently associate the terms 'dirty' and 'thieves' with Gypsies when they have to answer 'as the French would do in general' than when they express themselves personally. Similarly, the authors (Deschamps, Guimelli, 2004) show that participants are more likely to agree with the idea that 'insecurity' is linked to the suburbs, young people and/or foreigners, when they express themselves 'as the French/Swiss would do in general' (two populations were interviewed in this study, one French and the other Swiss), than when they are asked to respond on their own behalf. This technique has been the subject of several researches involving very diverse objects such as 'the North Africans' (Abric, 2003), 'the Muslims' (Flament, Guimelli, Abric, 2006), 'the working woman' (Flament, Guimelli, Abric, 2006), or 'alcohol' (Lo Monaco et al., 2009). All confirm the patterns of results initially highlighted by Guimelli and Deschamps (2000).

\section{Normative decontextualisation}

This method consists of manipulating the interviewer's presentation (Abric, 2003). Flament et al. (2006) show that when individuals are led to express their representation of 'Islam', they express more agreement with the idea that this religion goes against the democratic values of France when faced with an interviewer 
introducing herself with a French name ('Céline') than when faced with an interviewer introducing herself with a name of Maghreb origin ('Yamina'). At the same time, individuals express their adherence to socially desirable beliefs when they feel that it is useful, even if they do not necessarily subscribe to them. For example, again in the study conducted by Flament et al. (2006), an individual shows more agreement with the idea that Islam is a religion of tolerance when confronted with an interviewer introduced as 'Yamina' than when confronted with an interviewer introduced as 'Céline'. This type of procedure therefore facilitates the expression of certain socially stigmatised opinions when individuals are faced with the 'right' person, i.e. one who should not or hardly judge negatively the sender for their opinions. This explains why it has been used in several searches involving various objects. Thus, with regards to the representation of alcohol, there are clear differences between a situation where participants think they are responding to the academic solicitation of a student versus an association for the prevention of alcoholism among young people (Lo Monaco et al., 2009; Lo Monaco, Guimelli, 2011). In the same vein, responding to an interviewer belonging to the gypsy community (versus the French community) very strongly attenuates the sociorepresentational elements expressed with regards to Gypsies (Piermattéo et al., 2014).

\section{The (de)legitimisation of counter-normative beliefs}

Research conducted by Guimelli, Deschamps and Lo Monaco (2010) has highlighted the relevance of using the legitimisation process (Kelman, 1958, 2001) to study the mute zone of social representations. This research is part of the lawsuit brought against the weekly newspaper Charlie Hebdo regarding the publication of Muhammad cartoons, initially published by the Danish daily magazine Jylland Posten and taken up by the daily newspaper France Soir. The authors predicted that the legitimacy of a judicial decision could make it possible to unmask certain counter-normative beliefs. Students were questioned about the social representation of Muslims in two times: before and after the decision of Justice, which relaxed the satirical weekly newspaper. The media immediately seized the issue and celebrated the victory of freedom of expression. Thus, in France, a wave of information approving such a decision surfaced.

As part of the study and following an inter-subject design, the authors asked participants to complete a questionnaire using the substitution technique. Some of the participants had to answer on their own behalf, under standard survey conditions ('normal' instruction), while others had to answer the questionnaire as the French in general ('substitution' instruction). Some of the participants were interviewed prior to the Justice decision and release of the discharge, while some were interviewed after the decision. During the second phase of data collection, the authors also asked participants if they were aware of the Court's decision.

In accordance with the hypotheses formulated by the authors, before the decision of Justice and therefore at the first stage of the research, we observed the results usually obtained through the manipulation of the instruction of expression. Indeed, when participants are under the 'substitution' instruction, they show more agreement with the counter-normative aspects related to the social representations of Muslims (unmasking) than participants under the 'normal' instruction (masking). However, after the announcement of the Court's decision and Charlie 
Hebdo's acquittal, the results reveal a cancellation of this difference, and therefore show a convergence of responses towards an agreement with the counternormative aspects of representation. This result shows that the official position taken by the courts leads to the legitimisation of the counter-normative beliefs of representation and, consequently, their unmasking. It corresponds to the results observed by Kelman in the spring of 1954 when he was pursuing his investigations on social influence in relation to the desegregation of public schools.

Further analysis of the data also showed that these results were even more pronounced when they took into account the participants' awareness of the Court's decision after the trial. In fact, only informed subjects express their agreement with a counter-normative item, thus unmasking their beliefs in 'normal' instructions. These results are in favour of taking into account the institutional legitimisation of beliefs within the framework of the study of the mute zone of social representations.

While all of these studies demonstrate the existence of mute zones about various representational fields, the question of the socio-cognitive processes involved in this phenomenon has given rise to several hypotheses (Flament, Milland, 2010).

\section{Theoretical interpretations}

For some authors (Abric, 2003; Guimelli, Deschamps, 2004; Flament, Milland, 2010; Milland, Flament, 2010), the results observed in the paradigmatic framework of the mute zone relate to the effect of normative pressure that represses a socially proscribed discourse or encourages a socially prescribed discourse. Substitution instruction, normative decontextualisation or private context would make it possible to lift this normative pressure. In other words, expressing oneself in the place of others, for example, would make it possible to reduce the level of involvement of the individual who would find themselves somehow freed from the weight of normative pressure. This would lead them to express more counternormative opinions and less pro-normative ones.

This interpretation is supported by several studies on 'subtle or veiled racism', whose expression is much less brutal than that of blatant racism (Pettigrew, Meertens, 1995). In the same vein, Pérez and Mugny (1993) and several authors around them (see Falomir-Pichastor et al., 2004), have developed a series of studies that explore, within the framework of social influence processes, the action of a 'non-discrimination norm', which leads to self-censorship of xenophobic, racist, homophobic, sexist and other stigmatising discourses. The substitution instruction, the decontextualisation or the private context would thus lift this interdictory norm that weighs on the expression of one's own answers.

However, an alternative explanation has been suggested by Flament and Rouquette (2003) regarding the substitution instruction effect: the possible transparency of a social representation. For the authors, the French participants know what most French people think about Gypsies, Islam or the reasons for insecurity. When they are asked to express themselves in the place of the French population, they then try to show clear-sightedness. This is shown in a study well known in the field of racist stereotypes. Devine (1989) used a scale designed to measure prejudice against the African-American population (considered reliable, at least in 
the United States and at this time), and divided a group of students (Americans of white ethnicity) according to their level of prejudice (strong or weak). She asked all participants to write down their knowledge of cultural stereotypes about African-Americans and not their personal beliefs: 'How do you think people see black people?' The answers show that, no matter how strong their prejudices are, the stereotype is known to all subjects. This closely resembles the results observed by Guimelli and Deschamps (2000) about gypsies: as a standard rule, the $26 \%$ of subjects who declare themselves to be 'thieves' may be more xenophobic than the others (although this form of questioning is not conceived to study racism). But the substitute instruction, which is the exact equivalent of the one used by Devine, reveals that $64 \%$ of respondents are aware of the stereotype that accuses gypsies of being thieves.

The question of this transparency caused by the use of the substitution instruction has been tested experimentally by Guegan, Moliner and Vidal (2013). Based on work on computer-mediated communications, the authors cross-referenced the context of expression (i.e., standard vs. substitution) with the data collection method (i.e., paper/pencil vs. online questionnaire) regarding the social representation of the Roms. If the collection method affects the responses in standard instructions with a greater expression of counter-normative aspects online than in a paper/pencil situation, the authors observe a stability of the counter-normative responses in substitution condition regardless of the modality of the collection method (i.e., paper/pencil vs. online). The results observed in substitution instruction thus show that the valence scores (i.e., positivity/negativity of responses) are statistically equivalent in the on-line and paper/pencil conditions. According to the authors, the stability of the responses produced in substitution instruction reveals the intervention of a process of transparency. In addition, measures of adherence/differentiation to the responses expressed, carried out under both standard and substitution measures, reinforce this interpretation. Indeed, while the online context should make it easier for participants to admit to adhering to the opinions that they supposedly just unmasked, the authors observe, in substitution, that the adherence scores for the reference group's opinion do not differ between the two collection methods (online vs. paper/pencil).

Finally, a third hypothesis has been put forward to account for the effect of the substitution instruction: the intervention of an implicit process of self/others comparison (Chokier, Moliner, 2006; Chokier, Rateau, 2009). By attributing more socially valued opinions to themselves and more socially devalued opinions to others, individuals would seek to maintain a positive self-assessment (Tesser, 1988) and expose themselves to either false consensus bias (Marks, Miller, 1987; Mullen et al., 1985; Ross, Green, House, 1977) or false uniqueness bias (for a review see Chambers, 2008) depending on the desirability or undesirability of the opinions involved. Thus, when participants express themselves about undesirable opinions or behaviours, they would tend to overestimate the frequency of these opinions or behaviours in the population (i.e., false consensus effect). The opposite effect occurs with regards to socially desirable opinions or behaviours: individuals tend to underestimate their frequency in the population (i.e., false uniqueness effect), thus echoing Codol's (1984. P. 317) point of view: 'the more an item is considered normative by a given subject, the more that subject tends to declare that this 
item characterises them more than the others' (see also Hardoin, Codol, 1984). This hypothesis makes it possible to understand why the effect of substitution instructions is observed both for objects involving counter-normative responses (i.e., 'sensitive' objects) and for socially valued objects (e.g., objects related to environmental issues, cf. Chesterman, 2015; Rateau, Chesterman, 2017).

Flament, Guimelli and Abric (2006) will finally summarise the phenomenon by indicating that individuals always select the expressible aspects of representation according to the normative stake they perceive in the situation they find themselves in. In the end, whatever the processes at stake, the context in which the expression takes place leads the individual to summon what is, in relation to the object, socially valued and socially devalued.

Whether it is a question of formulating what is inexpressible in a standard condition, of expressing a certain transparency about undesirable opinions, or a question of expressing what allows the individual to value themself in relation to others, it is imperative that the individual knows what is valued or not valued and that they convoke this knowledge in order to provide their answer. In other words, if the different techniques used, depending on the case, increase counter-normative responses and reduce pro-normative responses, it is above all because they highlight what is normatively prescribed and proscribed, they activate what is socially desirable and undesirable - in short, they determine a form of recall of what is pro-normative and counter-normative according to the object.

\section{Research perspectives}

\section{The issue of behavioural measurement}

Few studies have mobilised behavioural measures within the framework of the study of social masking and the mute zone of social representations. To our knowledge, only one study has been carried out (Guimelli et al., 2012; Hidalgo, 2012) in the context of a gambling situation ('prisoner's dilemma'). This study showed that participating students frequently gambled their first move more competitively than cooperatively when they thought they were playing with a gypsy partner rather than when they thought they were interacting with a student partner.

As pointed out by Guimelli and Lo Monaco (2016), this work illustrates the interest that should be taken in behavioural measures when one is interested in the unsaid aspects of social thought. Clearly, behavioural measures avoid many of the inconveniences intrinsic to declarative measurement. We therefore believe that it is necessary to go further within the exploration of these measures in order to overcome the inherent limitations of social desirability effects. Therefore, it seems opportune to come back to the work done on the social representations of the gypsy community by modifying the measures carried out. The work conducted on this representation consisted of asking participants to associate the first words that came to their mind when the term 'gypsies' was evoked. As a reminder, whether by using the substitution technique (Guimelli, Deschamps, 2000) or by varying the anonymity versus the visibility of the participants (Piermattéo et al., 2014), empirical studies have revealed that the term 'thief' did not appear spontaneously. Describing gypsies as 'thieves' supposes to assign them dishonest intent and demonstrate all the distrust they are victim of. Moreover, far from being merely 
descriptive, some terms, the word 'thief' being probably one of them, have a prescriptive dimension (Flament, 1994). Thus, to say that gypsies are thieves presupposes the activation of a behavioural prescription such as: 'gypsies are thieves, so it is necessary to beware of them'. If such descriptive cognition of a population is accompanied by a prescriptive dimension of behaviours, it is then possible to glimpse a path conducive to behavioural measurement. It therefore remains to imagine an experimental situation activating this prescription. Distrust refers to vigilance and protective behaviour. Whenever someone we don't trust is standing next to us, we tend, for example, to move our belongings closer to us. This type of behaviour is regularly observed in closed spaces such as public transport. It goes without saying that these attributions of intentions are strongly determined by our system of thought, as shown by the results highlighted by Allport and Postman (1947) within the framework of the relay communication paradigm. The transformations of the message observed in this experiment show the intervention of a body of knowledge relating to the African-American population in the United States. Because of their orientation function (Abric, 1976, 1994; Doise, 1973), social representations can be considered as playing a role in the anticipation of behaviours. Consequently, the adoption of protective behaviours on the part of participants actually confronted with gypsies would potentially show that the latter's behaviours are determined by representational aspects that are not, however, spontaneously declared.

\section{Mute zone, social power and disinhibition}

In 2003, Keltner, Gruenfeld and Anderson (2003) reported on a model that predicts a tendency for 'high power' individuals to disinhibition and a tendency for 'low power' individuals to inhibition. Disinhibition is part of the social consequences of power and is a modality of approach behaviour. It makes it possible to break free from social norms. Thus, the priming of a high level of power leads to a stronger expression of prejudices and an increase in adherence to legitimising ideologies (De Oliveira, Dambrun, Guimond, 2008; De Oliveira, Guimond, Dambrun, 2012). Other studies show that those who are primed with 'high power' use stereotypes to qualify those primed with 'low power', while the reverse occurs significantly less (Vescio et al., 2009).

These results are similar to those highlighted by Degraeve (2015) partly devoted to the study of the effects of power (high vs. low) in a situation of anonymity vs. visibility (private vs. public context of expression). The author shows that participants primed with high power report significantly lower social desirability scores than participants primed with low power. Indeed, 'high power' primed individuals tend to make more negative judgments about a target in a private context than 'low power' primed individuals, but make more positive judgments in a public context. Degraeve (2015) followed the path of social responsibility activated in the public context among the 'high power' primed individuals but the results only partially validated his hypotheses. Taken as a whole and in a context of deprivation of expression, the data show a tendency towards disinhibition and are encouraging for further investigation of masking and unmasking effects.

Given these different aspects, it seems possible to use this variable in the study of masking and unmasking. In our opinion, it is from the work carried out by 
Swingle (1970) that it is possible to glimpse some interesting ways of operationalisation. Within the framework of paradigms such as 'experimental games', Swingle (1970) proposes a manipulation of power by manipulating compensation matrices provided to participants. It consists in manipulating the remuneration which determines a level of power at stake in the relationship between the two players. This power induction pathway would remove the major limitations inherent in power activation methods. However, it may be argued that the experimental gambling situation requires a significant number of trials. Nevertheless, the goal here is not to observe cooperative or competitive behaviours, but to induce a different level of power between players. In addition, just like the 'role-playing' type of priming methods (e.g., Anderson, Berdahl, 2002; Dubois, Rucker, Galinsky, 2010; Galinsky, Gruenfeld, Magee, 2003; Maner et al., 2007; Maner, Mead, 2010; Overbeck, Park, 2001; Richeson, Ambady, 2003), quite common in the context of power priming, the advantage lies in the fact that only one handover is necessary in order to place one individual in a situation of high power and the other in a situation of low power, which is not the case for example with autobiographical recall (Galinsky, Gruenfeld, Magee, 2003). While this priming method produces satisfactory results, it is then possible to carry out measurements on a given social group (Degraeve, 2015) and to systematically explore the effects of power on masking and unmasking strategies in relation to positions on counter-normative aspects.

\section{Substitution paradigm and attitudinal and behavioural adjustment}

As noted above, one of the major effects of the substitution instruction is that it activates in the participant what is normatively prescribed and proscribed for the object in question. The question then arose as to whether this pro- or counter-normative activation might have an effect on participants' subsequent behaviour regarding the object. Much work has indeed shown the role that the activation of pro- or counter-normative norms can play on behaviour. This is notably the case with Cialdini's work on normative focus (Cialdini et al., 1990, 1991; Kallgren et al., 2000; Reno et al., 1993), which shows that when a given situation activates a prescriptive norm, the individual tends to conform to it at a behavioural level. It could therefore be hypothesised that the activation of a prescriptive norm, induced by the substitution instruction, would be able to provoke a phenomenon of 'behavioural adjustment'. In other words, it was expected that, following a substitutive response, the individual would adjust their behaviour to what is socially desirable. This is shown by a series of studies conducted on environmental objects (Chesterman, Rateau, 2012a, 2012b; Chesterman, 2015, Rateau, Chesterman, 2017). For example, participants invited to respond to an environmental attitude scale provide much more negative responses when answering on behalf of the French in general than when answering on their own behalf. Subsequently, these same participants report being more involved in pro-environmental behaviours than others, whether it be declaring a greater desire to adopt eco-responsible behaviours, installing dry toilets in their homes, respecting seismic standards in the construction of their homes, or investing in a shared garden project. This effect goes beyond behavioural intent alone to guide actual behaviour. For example, individuals who have responded to an environmental attitude scale with a substitution instruction are subsequently more likely than others to sign petitions in favour of pro- 
environmental actions and to effectively participate in a clean-up event. In other words, denigrating others on an environmental dimension seems to activate a prescriptive pro-environmental norm to which participants subsequently adjust their behaviour. Other work is currently underway on this issue, which opens up promising paths for research and application.

In the same vein and more recently, a series of research studies using the substitution paradigm has been conducted on moral judgment (Trémolière, Rateau, submitted). The results show that individuals faced with a series of moral dilemmas under substitution instruction provide more utilitarian answers (i.e., it is moral to sacrifice the life of an innocent person if this sacrifice saves other lives) than those faced with standard instructions who are more deontic (i.e., it is not moral to sacrifice an innocent person, regardless of the positive consequences). These results, particularly robust as indicated by a meta-analysis applied to a set of six replications, indicate the existence of a deontic social norm to which individuals subscribe while they believe others do not conform to that norm. However, the subsequent effects on the judgment of others, whether assessing another participant who allegedly provided deontic vs. utilitarian responses or choosing between two political candidates, one deontic and one utilitarian, are not apparent. Again, research must continue in order to refine our understanding of the processes and effects of substitution.

\section{Conclusion}

Taken as a whole, the elements relating to the assessment and research perspectives demonstrate the value of intensifying studies devoted to the expression of socially desirable and undesirable aspects of social representations. Clearly, at a time when opinions are expressed more and more rapidly and when digital social communications are at the heart of concerns, it is more than ever necessary to understand the mechanisms at play in the expression of these opinions whose determinants are of an ideological and socio-representational nature. However, understanding these mechanisms, and therefore the processes, presupposes mastering the reliability of the responses produced or understanding the ways in which they are expressed. As such, whether at a theoretical or methodological level, research on the mute zone of social representations has an important political and social significance: research makes it possible to grasp the subtleties of the expression of common sense and reveal the social conditions of this expression.

\section{References}

Abric, J.C. (1976). Jeux, conflits et représentations sociales. Aix-en-Provence: Thèse de Doctorat d'Etat de l'Université de Provence.

Abric, J.-C. (1994). Pratiques sociales et représentations. Presses Universitaires de France.

Abric, J.-C. (2003). La recherche du noyau central et de la zone muette des représentations sociales. In J.-C. Abric (Ed.), Méthodes d'études des représentations sociales (pp. 59-80). Ramonville Saint Agne: Érès.

Albarracin, D., Johnson, B.T., \& Zanna, M.P. (2005). Handbook of attitudes. New York: Psychology Press.

Allport, G.W., \& Postman, L. (1947). The psychology of rumor. Henry Holt. 
Anderson, B.A., Silver, B.D., \& Abramson, P.R. (1988). The effects of the race of the interviewer on race-related attitudes of black respondents in SRC/CPS national election studies. Public Opinion Quarterly, 52(3), 289-324. https://doi.org/10.1086/269108

Anderson, C., \& Berdahl, J.L. (2002). The experience of power: Examining the effects of power on approach and inhibition tendencies. Journal of Personality and Social Psychology, 83(6), 1362-1377. https://doi.org/10.1037/0022-3514.83.6.1362

Campbell, B. (1981). Race-of-interviewer effects among southern adolescents. Public Opinion Quarterly, 45, 231-234. http://dx.doi.org/10.1086/268654

Chambers, J.R. (2008). Explaining false uniqueness: Why we are both better and worse than others. Social and Personality Psychology Compass, 2(2), 878-894. https://doi.org/10.1111/j.17519004.2008.00076.x

Chesterman, A. (2015). Des prescriptions aux comportements de protection du risque sismique en région Provence-Alpes-Cote-d'Azur. Développement d'un paradigme substitutif. Aix-en-Provence: Thèse de doctorat de l'université d'Aix-Marseille.

Chesterman, A., \& Rateau, P. (2012a). Implicit social comparison through self-other substitution and its role in behaviour change. $30^{\text {th }}$ International Congress of Psychology, Cap Town (South Africa), 22-27 July 2012.

Chesterman, A., \& Rateau, P. (2012b). Using self-other substitution to induce pro-environmental behaviour: A new line in behaviour change research. $22^{\text {nd }}$ Conference of the International Association for People-Environment Studies, Glasgow (Scotland), 24-29 June 2012.

Chokier, N., \& Moliner, P. (2006). La "zone muette" des représentations sociales. Pression normative et/ou comparaison sociale? Bulletin de Psychologie, 3, 281-286. https://doi.org/10.3917/bupsy.483.0281

Chokier, N., \& Rateau, P. (2009). Représentations sociales et comparaison soi-autrui. In P. Rateau \& P. Moliner (Eds.), Représentations sociales et processus sociocognitifs (pp. 31-44). Rennes: Presses Universitaires de Rennes.

Cialdini, R.B., Kallgren, C.A., \& Reno, R.R. (1991). A focus theory of normative conduct: A theoretical refinement and reevaluation of the role of norms in human behavior. In L. Berkowitz (Ed.), Advances in Experimental Social Psychology (vol. 24, pp. 201-234). San Diego, CA: Academic Press.

Cialdini, R.B., Reno, R.R., \& Kallgren, C.A. (1990). A focus theory of normative conduct: Recycling the concept of norms to reduce littering in public places. Journal of Personality and Social Psychology, 58, 1015-1026. https://doi.org/10.1037/0022-3514.58.6.1015

Codol, J.-P. (1984). La perception de la similitude interpersonnelle: influence de l'appartenance catégorielle et du point de référence de la comparaison. L'Année Psychologique, 84(1), 43-56. https://www.persee.fr/doc/psy_0003-5033_1984_num_84_1_29000

Davis, D.W. (1997). Nonrandom measurement error and race of interviewer effects among African Americans. Public Opinion Quarterly, 61, 183-207. http://dx.doi.org/10.1086/297792

De Oliveira, P., Dambrun, M., \& Guimond, S. (2008). L'effet de la dominance sociale sur les idéologies de légitimation: le rôle modérateur de l'environnement normatif. Revue internationale de psychologie sociale, 21(4), 115-150.

De Oliveira, P., Guimond, S., \& Dambrun, M. (2012). Power and legitimizing ideologies in hierarchy-enhancing vs. hierarchy-attenuatin environments. Political Psychology, 33(6), 867-885. https://doi.org/10.1111/j.1467-9221.2012.00909.x

Degraeve, B., Granié, M.-A., Pravossoudovitch, K., \& Lo Monaco, G. (2015). Social representations associated with men and women drivers among French adolescents and adults. Effects of the perceiver's age, sex, and socioeconomic status. Transportation Research Part F: Traffic Psychology and Behaviour, 34, 1-17. https://doi.org/10.1016/j.trf.2015.07.019

Deschamps, J.C., \& Guimelli, C. (2002). La composante émotionnelle des représentations sociales: émotions rapportées et tendances à l'action dans une étude comparative des 
représentations sociales de l'insécurité en France et en Suisse. Nouvelle Revue de Psychologie Sociale, 1(1), 78-84.

Deschamps, J.C., \& Guimelli, C. (2004). L'organisation interne des représentations sociales de la sécurité/insécurité et l'hypothèse de la «zone muette». In J.-L. Beauvois, R.-V. Joule \& J.-M. Monteil (Eds.), Perspectives cognitives et conduites sociales, (vol. 9, pp. 105-130). Rennes: Presses universitaires de Rennes.

Devine, P.G. (1989). Stereotypes and prejudice: Their automatic and controlled components. Journal of Personality and Social Psychology, 56, 5-18. https://doi.org/10.1037/00223514.56.1.5

Doise, W. (1973). Relations et représentations intergroupes. In S. Moscovici (Ed.), Introduction à la psychologie sociale (pp. 195-214). Larousse.

Dubois, D., Rucker, D.D., \& Galinsky, A.D. (2010). The accentuation bias: Money literally larger (and sometimes smarter) than powerless. Social Psychological and Personality Science, 1(3), 199-205. https://doi.org/10.1177/1948550610365170

Falomir-Pichastor, J.-M., Muñoz, D., Invernizzi, F., \& Mugny, G. (2004). Perceived in-group threat as a factor moderating the influence of in-group norms on discrimination against foreigners. European Journal of Social Psychology, 34, 135-153. https://doi.org/10.1002/ejsp.189

Fazio, R.H., \& Olson, M.A. (2003). Implicit measures in social cognition research: Their meaning and use. Annual Review of Psychology, 54, 297-327. https://doi.org/10.1146/annurev.psych.54.101601.145225

Fazio, R.H., Jackson, J.R., Dunton, B.C., \& Williams, C.J. (1995). Variability in automatic activation as an unobtrusive measure of racial attitudes: A bona fide pipeline? Journal of Personality and Social Psychology, 69(6), 1013-1027. https://doi.org/10.1037/00223514.69.6.1013

Fazio, R.H., Sanbonmatsu, D.M., Powell, M.C., \& Kardes, F.R. (1986). On the automatic activation of attitudes. Journal of Personality and Social Psychology, 50(2), 229-238. https://doi.org/10.1037/0022-3514.50.2.229

Finkel, S.E., Guterbock, T.M., \& Borg, M.J. (1991). Race-of-interviewer effects in a preelection poll Virginia 1989. Public Opinion Quarterly, 55(3), 313-330. https://doi.org/10.1086/269264

Flament, C. (1994). Le plaisir et la rémunération dans la représentation sociale du travail. Les Cahiers Internationaux de Psychologie Sociale, 23, 61-69.

Flament, C., \& Milland, L. (2010). La substitution dans les études de représentations sociales: quel processus impliqué? Psychologie Française, 55(3), 195-210. https://doi.org/10.1016/j.psfr.2010.05.003

Flament, C., \& Rouquette, M.-L. (2003). Anatomie des idées ordinaires. Paris: Armand Colin.

Flament, C., Guimelli, C., \& Abric, J. C. (2006). Effets de masquage dans l'expression d'une représentation sociale. Les Cahiers Internationaux de Psychologie Sociale, 1, 15-31. https://doi.org/10.3917/cips.069.0015

Galinsky, A.D., Gruenfeld, D.H., \& Magee, J.C. (2003). From Power to Action. Journal of Personality and Social Psychology, 85(3), 453-466. https://doi.org/10.1037/00223514.85.3.453

Gilbert, D.T., \& Hixon, J.G. (1991). The trouble of thinking: Activation and application of stereotypic beliefs. Journal of Personality and social Psychology, 60(4), 509-517. https://doi.org/10.1037/0022-3514.60.4.509

Goffman, E. (1959). The Presentation of Self in Everyday Life. New York (NY): Doubleday.

Greenwald, A.G., \& Banaji, M.R. (1995). Implicit social cognition: Attitudes, self-esteem and stereotypes. Psychological Review, 102(1), 4-27.

Guegan, J., Moliner, P., \& Vidal, J. (2013). Enquête en ligne et masquage/démasquage des opinions sensibles: une autre approche des effets de contexte. Revue Internationale de Psychologie Sociale, 26(1), 101-124. 
Guimelli, C., \& Deschamps, J.C. (2000). Effets de contexte sur la production d'associations verbales. Les Cahiers Internationaux de Psychologie Sociale, 47-48, 44-54.

Guimelli, C., Hidalgo, H., Piermattéo, A., Lo Monaco, G., \& Abric, J.C. (2012, Juin). Zone muette des représentations sociales et comportements. 11ème Conférence Internationale sur les Représentations Sociales, Evorà, Portugal.

Hardoin, M., \& Codol, J.P. (1984). Self and others descriptions: The influence of the descriptions order on categories used. Cahiers de Psychologie Cognitive, 4, 295-302.

Hidalgo, M. (2012). Représentations sociales et contextes: études autour de l'expression et des comportements en lien avec les éléments masqués. Aix-en-Provence: Thèse de doctorat de l'Université d'Aix-Marseille.

Himmelfarb, S., \& Lickteig, C. (1982). Social desirability and the randomized response technique. Journal of Personality and Social Psychology, 43(4), 710-717. https://doi.org/10.1037/0022-3514.43.4.710

Jellison, J., \& Green, J. (1981). A self-presentation approach to the fundamental attribution error: The norm of internality. Journal of Personality and Social Psychology, 40, 643-649. https://doi.org/10.1037/0022-3514.40.4.643

Jodelet, D. (1989). Folies et représentations sociales. Paris: Presses universitaires de France.

Jones, E.E., \& Sigall, H. (1971). The bogus pipeline: A new paradigm for measuring affect and attitude. Psychological Bulletin, 76, 349-364. https://doi.org/10.1037/h0031617

Kallgren, C.A., Reno, R.R., \& Cialdini, R.B. (2000). A focus theory of normative conduct: When norms do and do not affect behavior. Personality and Social Psychology Bulletin, 26, 1002-1012. https://doi.org/10.1177/01461672002610009

Kelman, H.C (1958). Compliance, identification, and internalization: Three processes of attitude change. Journal of Conflict Resolution, 2(1), 51-60.

Kelman, H.C. (2001). Reflections on social and psychological processes of legitimization and delegitimization. In J.T. Jost \& B. Major (Eds.), The psychology of legitimacy. Emerging perspectives on ideology, justice, and intergroup relations (pp. 54-73). Cambridge: Cambridge University Press.

Keltner, D., Gruenfeld, D.H., \& Anderson, C. (2003). Power, approach, and inhibition. Psychological Review, 110(2), 265-284. https://doi.org/10.1037/0033-295X.110.2.265

Klein, O., Licata, L., Azzi, A.E., \& Durala, I. (2003). "How European am I?" Prejudice Expression and the Presentation of Social Identity. Self \& Identity, 2, 251-264. https://doi.org/10.1080/15298860309025

Klein, O., Livingston, R.W., \& Snyder, M. (2005). Être ou ne pas être politiquement correct? La relation entre préjugé et expression d'impressions stéréotypées en fonction du selfmonitoring. Les Cahiers Internationaux de Psychologie Sociale, 67/68, 55-64.

Kuran, T. (1995). Private truths, public lies: The social consequences of preference falsification. Cambridge (MA): Harvard University Press.

Lajunen, T., \& Summala, H. (2003). Can we trust self-reports of driving? Effects of impression management on driver behaviour questionnaire responses. Transportation research part F: Traffic psychology and behaviour, 6(2), 97-107. https://doi.org/10.1016/S1369-8478(03)00008-1

Lo Monaco, G., \& Guimelli, C. (2011). Hegemonic and polemical beliefs: Culture and consumption in the social representation of wine. The Spanish Journal of Psychology, 14(1), 232-245. https://10.5209/rev_SJOP.2011.v14.n1.21

Lo Monaco, G., Lheureux, F., Chianèse, L., Codaccioni, C., Halimi-Falkowicz, S., \& Cano, P. (2009). Contexte d'expression, statut social des intervenants de santé et production d'un discours normatif: le cas de l'alcool et des jeunes. Pratiques psychologiques, 15(3), 367-386. https://doi.org/10.1016/j.prps.2008.02.002 
Maner, J.K., \& Mead, N.L. (2010). The essential tension between leadership and power: When leaders sacrifice group goals for the sake of self-interest. Journal of Personality and Social Psychology, 99(3), 482-497. https://doi.org/10.1037/a0018559

Maner, J.K., Gailliot, M.T., Butz, D.A., \& Peruche, B.M. (2007). Power, risk and the status quo: Does power promote riskier or more conservative decision making? Personality and Social Psychology Bulletin, 33(4), 451-462. https://doi.org/10.1177/0146167206297405

Marks, G., \& Miller, N. (1987). Ten years of research on the false-consensus effect: An empirical and theoretical review. Psychological Bulletin, 102, 72-90. https://doi.org/10.1037/00332909.102.1.72

Milland, L., \& Flament, C. (2010). Les facettes d'une représentations sociale: nouvelle approche des effets de masquage. Les Cahiers Internationaux de Psychologie Sociale, 2(86), 213-240.

Moscovici, S. (1961). La psychanalyse, son image et son public. Paris: Presses Universitaires de France.

Mullen, B., Atkins, J.L., Champion, D.S., Edwards, C., Hardy, D., Story, J.E., \& Venderklok, M. (1985). The false consensus effect: A meta-analysis of 115 hypothesis tests. Journal of Experimental Social Psychology, 21, 262-283. https://doi.org/10.1016/00221031(85)90020-4

Overbeck, J.R., \& Park, B. (2001). When power does not corrupt: Superior individuation processes among powerful perceivers. Journal of Personality and Social Psychology, 81(4), 549-565. https://doi.org/10.1037/0022-3514.81.4.549

Pérez, J.A., \& Mugny, G. (1993). Influences sociales: la théorie de l'élaboration du conflit. Neuchâtel: Delachaux et Niestlé.

Pettigrew, T.F., \& Meertens, R.W. (1995). Subtle and blatant prejudice in Western Europe. European Journal of Social Psychology, 25(1), 57-75. https://doi.org/10.1002/ejsp.2420250106

Piermattéo, A., Lo Monaco, G., Moreau, L., Girandola, F., \& Tavani, J.L. (2014). Context variations and pluri-methodological issues concerning the expression of a social representation: The example of the Gypsy Community. The Spanish Journal of Psychology, 17, 1-12. https://10.1017/sjp.2014.84

Rateau, P., \& Chesterman, A. (2017). I'm more eco-friendly than other people and I'll prove it: Substitution and pro-environmental behaviors. IAPS 2017 Symposium, Dar Es Salaam (Tanzanie), 27-29 september 2017.

Reno, R.R., Cialdini, R.B., \& Kallgren, C.A. (1993). The transsituational influence of social norms. Journal of Personality and Social Psychology, 64, 104-112. https://doi.org/10.1037/0022-3514.64.1.104

Richeson, J.A., \& Ambady, N. (2003). Effects or situational power on automatic racial prejudice. Journal of Experimental Social Psychology, 39(2), 177-183. https://doi.org/10.1016/S0022-1031(02)00521-8

Ross, L., Greene, D., \& House, P. (1977). The "false consensus effect": An egocentric bias in social perception and attribution processes. Journal of Experimental Social Psychology, 13(3), 279-301. https://doi.org/10.1016/0022-1031(77)90049-X

Schuman, H., \& Converse, J.M. (1971). The effects of black and white interviewers on black responses in 1968. Public Opinion Quarterly, 35(1), 44-68. https://doi.org/10.1086/267866

Stangor, C., Swim, J.K., Van Allen, K.L., \& Sechrist, G.B. (2002). Reporting discrimination in public and private contexts. Journal of Personality and Social Psychology, 82(1), 69-74. https://doi.org/10.1037/0022-3514.82.1.69

Sudman, S., \& Bradburn, N.M. (1974). Response effects in surveys: A review and synthesis. Chicago: Aldine Publishing.

Swingle, P.G. (1970). Exploitative behavior in non-zero-sum games. Journal of Personality and Social Psychology, 16(1), 121-132. https://doi.org/10.1037/h0029844 
Tesser, A. (1988). Toward a self-evaluation maintenance model of social behavior. In L. Berkowitz (Ed.), Advances in experimental social psychology (vol. 21, pp. 181-227). New York: Academic Press.

Trémolière, B., \& Rateau, P. (Submitted). You're heartless, I'm less: Self-image and social norm in moral judgment. https://psyarxiv.com/9qnpy/

Vescio, T.K., Gervais, S.J., Heiphetz, L., \& Bloodhart, B. (2009). The stereotypic behaviors of the powerful and their effect on the relatively powerless. In T.D. Nelson (Ed.), Handbook of prejudice, stereotyping, and discrimination (pp. 247-265). Psychology Press.

Warner, S.L. (1965). Randomized response: A survey technique for eliminating evasive answer bias. Journal of the American Statistical Association, 60(309), 63-69. https://10.1080/01621459.1965.10480775

Yzerbyt, V. (1997). Automaticité et contrôle. In J.-Ph. Leyens \& J.-L. Beauvois (Eds.), La psychologie sociale: l'ère de la cognition (vol. 3, pp. 173-189). Grenoble: Presses Universitaires de Grenoble.

\title{
Article history:
}

Received: 1 March 2021

Revised: 12 April 2021

Accepted: 10 May 2021

\section{For citation:}

Rateau, P., \& Lo Monaco, G. (2021). The mute zone of social representations and the effects of (un)masking: Review and prospects. RUDN Journal of Psychology and Pedagogics, 18(2), 375-390. http://dx.doi.org/10.22363/2313-1683-2021-18-2-375-390

\section{Bio notes:}

Patrick Rateau, Ph.D. in Psychology, Full Professor of Social Psychology at the Paul Valéry University Montpellier 3, EPSYLON Lab. EA 4556 (Montpellier, France). ORCID iD: https://orcid.org/0000-0001-6340-4676. E-mail: patrick.rateau@univ-montp3.fr

Grégory Lo Monaco, Ph.D. in Psychology, Full Professor in Education Sciences at Aix-Marseille University, ADEF Lab. UR 4671 (Aix-en-Provence, France). ORCID iD: https://orcid.org/0000-0003-1150-539X. E-mail: gregory.lo-monaco@univ-amu.fr

DOI 10.22363/2313-1683-2021-18-2-375-390

Теоретическая статья

\section{Скрытая зона социальных представлений и эффекты (де)маскировки: обзор и перспективы}

\author{
П. Рато ${ }^{1} \mathbb{D}^{\square}$, Г. Ло Монако $\mathbb{D}$ \\ ${ }^{1}$ Университет Поля Валери, Монпелье 3, \\ Франиузская Республика, 34080, Монпелье, Ruе du Professeur Henri Serres, $\partial .1$ \\ ${ }^{2}$ Университет Экс-Марсель, \\ Франиузская Республика, 13013, Марсель, Avепие Escadrille Normandie-Niemen, д. 52 \\ $\checkmark$ patrick.rateau@univ-montp3.fr
}

Аннотация. Двадцать лет назад Гимелли и Дешам (2000) выдвинули гипотезу о существовании скрытой зоны социальных представлений. По мнению этих ученых, некоторые части социальных представлений об объектах, описанных как «чувствитель- 
ные», не выявляются в обычных условиях исследования без дополнительных приемов. Этот фундаментальный вопрос на удивление поздно был поднят в литературе по социальным представлениям, но с тех пор он привлекает все больше внимания исследователей, работающих в данной области. В своей основополагающей работе Гимелли и Дешам предложили методологическую перспективу, позволяющую выявлять такие «невысказанные факты» и проложившую путь для дальнейших исследований, в которых были выдвинуты несколько теоретических интерпретаций и новых методов изучения «скрытой зоны» социальных представлений. При этом исследователям было важно как определить лежащие в основе «маскировки» процессы, так и разработать соответствующие инструменты для выявления контрнормативного содержания, потенциально связанного с определенными объектами представления. В настоящей работе предлагается подвести итоги этих двадцатилетних изысканий и наметить новые направления исследований, ориентированных, с одной стороны, на изучение социально-когнитивных процессов, связанных с феноменом скрытой зоны, а с другой - на поиск новых теоретических и методологических связей с другими концепциями, исследующими аналогичные вопросы.

Ключевые слова: скрытая зона, социальные представления, (де)маскировка, социальное сравнение, поведение, власть, методология

\section{История статьи:}

Поступила в редакцию: 1 марта 2021 г.

Принята к печати: 10 мая 2021 г.

\section{Для цитирования:}

Rateau P., Lo Monaco G. The mute zone of social representations and the effects of (un)masking: Review and prospects // Вестник Российского университета дружбы народов. Серия: Психология и педагогика. 2021. Т. 18. № 2. С. 375-390. http://dx.doi.org/10.22363/2313-1683-2021-18-2-375-390

\section{Сведения об авторах:}

Рато Патрик, Ph.D., профессор социальной психологии лаборатории EPSYLON EA4556 Университета Поля Валери, Монпелье 3 (Монпелье, Франция). ORCID iD: https://orcid.org/0000-0001-6340-4676. E-mail: patrick.rateau@univ-montp3.fr

Ло Монако Грегори, Ph.D., профессор наук об образовании ADEF лаборатории UR 4671 Университета Экс-Марсель (Экс-ан-Прованс, Франция). ORCID iD: https://orcid.org/0000-0003-1150-539X. E-mail: gregory.lo-monaco@univ-amu.fr 